\title{
Wykorzystanie niskoenergetycznego procesu CBT do łączenia stali wysokostopowej z miedzią
}

\author{
Using of low heat input CBT process \\ in joining of high-alloy steel with cooper
}

\section{Streszczenie}

W artykule przedstawiono zastosowanie technologii lutospawania łukowego z wykorzystaniem niskoenergetycznego procesu CBT (Controlled Brigde Transfer) na przykładzie łączenia stalowych blach wysokostopowych z blachami miedzianymi. Przedstawiono wyniki badań metalograficznych makro- i mikroskopowych oraz właściwości wytrzymałościowych otrzymanych połączeń. Wskazano na problemy występujące podczas lutospawania materiałów znacznie różniących się właściwościami oraz przedstawiono korzyści związane z wykorzystania niskoenergetycznych technologii lutospawania. Otrzymane wnioski pozwalają na stwierdzenie, że lutospawanie łukowe metodą CBT jest jedną z lepszych metodą łączenia stali wysokostopowych z miedzią.

Słowa kluczowe: niskoenergetyczne metody spawania, lutospawanie łukowe, metoda CBT, złącza różnoimienne, materiały trudno spawalne
Keywords: Low heat input welding methods, arc braze welding, CBT method, dissimilar joints, difficult to weld materials.

\section{Wstęp}

W przemyśle motoryzacyjnym, technologii budowy maszyn, w urządzeniach przemysłowych, a także w podzespołach elektronicznych i kompozytach coraz częściej zachodzi konieczność łączenia ze sobą materiałów konstrukcyjnych o odmiennych właściwościach. Spawanie płomieniowe czy powszechnie stosowane metody spawania łukowego w przypadku łączenia stali z aluminium, stali z miedzią czy stali z żeliwem nastręcza wykonawcom dużo problemów i często nie pozwala na wykonanie połączeń o wymaganych wysokich właściwościach użytkowych. Główne trudności przy spawaniu tych materiałów wynikają z ich odmiennego składu chemicznego i struktury, innej temperatury topnienia, przewodności cieplnej i elektrycznej, rozszerzalności cieplnej, wytrzymałości oraz potencjału elektrochemicznego i podatności do utleniania. W trakcie spawania prowadzi to do pojawienia się w złączu spawanym porów i pustek gazowych, pęknięć, braków przetopu i przyklejeń, niestabilnego jarzenia się łuku, utraty swoich pierwotnych właściwości wytrzymałościowych i antykorozyjnych oraz niekorzystnego stanu naprężeń i odkształceń w złączu w czasie procesu
Abstract

Low heat input CBT (Controlled Bridge Transfer) braze welding technology of joining high alloy stainless steel with cooper plates were described in this paper. Results of macro-, microscopic and mechanical properties tests were shown. Indicated the main problems during braze welding of material with significant different properties and shown a lot of benefits of using this technology. Achieved results can indicates that one of the better technologies of joining steels with cooper is braze welding.

Dr inż. Artur Czupryński, dr inż. Tomasz Kik, dr hab. inż. Jacek Górka - Politechnika Śląska.

Autor korespondencyjny/Corresponding author. artur.czuprynski@polsl.pl 
- proces CBT (Controlled Brigde Transfer), rozwiązanie japońskiej firmy DAIHEN,

- proces MAG - SpeedRoot, opracowane przez firmę LORCH.

Nowe technologie łączenia, zapewniły wyeliminowanie lub zminimalizowanie dotychczas występujących trudności. Większość z wymienionych powyżej metod wykorzystywane są w technice lutospawania - połączenia dobrze znanych procesów spawania i lutowania [1-14].

\section{Przebieg i wyniki badań}

Celem badań było określenie możliwości łączenia materiałów istotnie różniących się własnościami fizykochemicznymi wykorzystując proces lutospawania niskoenergetycznego CBT (Control Bridge Tranfser). Na podstawie badań nieniszczących i niszczących ocenione zostały kształt i jakość, oraz własności wytrzymałościowe i plastyczne złączy doczołowych typu miedź - stal nierdzewna austenityczna.

Próby lutospawania łukowego CBT wykonano na stanowisku zmechanizowanym wyposażonym w inwertorowe urządzenie spawalnicze DW-300 AC MIG Pulse japońskiej firmy OTC Daihen, przeznaczone do jakościowego, niskoenergetycznego spawania prądem stałym, przemiennym i pulsacyjnym.

Do wykonania złączy doczołowych użyto blach o wymiarach 3,5x150x100 mm wykonanych z miedzi Cu-ETP (zgodne z PN-EN 1652:1999) oraz stali nierdzewnej austenityczna 1H18N9 (zgodne z PN-EN 10088-2:2007). Skład chemiczny oraz własności wytrzymałościowe materiałów lutospawanych przedstawiono w tablicach I i II.

Do prób lutospawania użyto drutu elektrodowego litego CastoMag 45706 firmy Castolin, o średnicy 1,0 mm oraz rurko- wego bezszwowego drutu proszkowego firmy Drahtzug Stein oznaczonego symbolem Mecufil $903 \mathrm{Al}$, o średnicy 1,2 mm. Drut lity CastoMag 45706 przeznaczony jest do łączenia elementów miedzianych, ze stopów miedzi: Cu-Zn, Cu-Si, blach galwanizowanych cynkiem i aluminium oraz do nakładania powłok na stopy miedzi i metale nieżelazne. Skład chemiczny oraz własności mechaniczne stopiwa CuSi3Mn1 (zgodnie z PN-EN 13347:2004) zostały przedstawione w tablicy III.

Rurkowy bezszwowy drut proszkowy do lutospawania Mecufil 903Al to lut reakcyjny na bazie miedzi przeznaczony do lutospawania metodami MIG/MAG, TIG oraz PTA. Spoiwo odznacza się dobrą przydatnością do lutospawania konstrukcji z cienkościennych blach ocynkowanych o $R_{m}$ do $600 \mathrm{MPa}$, wysoką odpornością na porowatość przy łączeniu blach z warstwą cynku do $20 \mu \mathrm{m}$. Drut można wykorzystać przy zwarciowym i natryskowym przenoszeniu metalu w łuku podczas lutospawania łukowego. Mecufil 903 Al znajduje zastosowanie w sektorze blach cienkościennych, przemyśle samochodowym, w produkcji karoserii, obudów itp. Skład chemiczny lutu oraz własności mechaniczne zostały przedstawione w tablicy IV.

Każda blacha została przygotowana poprzez ukosowanie krawędzi łączonych na "V", powierzchnie blach zostały wyczyszczone papierem ściernym oraz odtłuszczone alkoholem etanolowym. Każdorazowo łączone elementy pozycjonowano względem siebie na stole wyposażonym w oprzyrządowanie mocujące, składające się z klamer usztywniających blachy. Dodatkowo, oprzyrządowanie zawierało także podkładkę stalową z wyżłobionym rowkiem, co ograniczało zbytnie odprowadzanie ciepła i pozwalało na poprawne formowanie grani lutospoiny [3]. Przed przystąpieniem do wykonania złączy, na podstawie wstępnych prób spawalniczych dobrano parametry procesu lutospawania, które zostały ujęte w tablicy V.

Tablica I. Skład chemiczny oraz własności mechaniczne miedzi Cu-ETP w stanie R220 (zgodne z PN-EN 1652:1999)

Table I. Chemical composition and mechanical properties of Cu-ETP cooper in R220 condition (according to PN-EN 1652:1999 standards)

\begin{tabular}{|c|c|c|c|c|c|c|}
\hline Nr wytopu & \multicolumn{4}{|c|}{ Skład chemiczny [\%] } & \multicolumn{2}{c|}{ Własności mechaniczne } \\
\hline \multirow{2}{*}{61} & $\mathrm{Cu}$ & $\mathrm{Bi}$ & $\mathrm{O}_{2}$ & $\mathrm{~Pb}$ & $\mathrm{R}_{\mathrm{m}^{\prime}} \mathrm{MPa}$ & $\mathrm{A}_{5^{\prime}} \%$ \\
\cline { 2 - 7 } & 99,98 & 0,0005 & 0,008 & 0,001 & 239 & 51,2 \\
\hline
\end{tabular}

Tablica II. Skład chemiczny oraz własności mechaniczne stali austenitycznej 1H18N9 (zgodne z PN-EN 10088-2:2007)

Table II. Chemical composition and mechanical properties of 1H18N9 austenitic stainless steel (according to PN-EN 10088-2:2007 standards)

\begin{tabular}{|c|c|c|c|c|c|c|}
\hline \multicolumn{7}{|c|}{ Skład chemiczny [\%] } \\
\hline $\mathrm{C}$ & $\mathrm{Mn}$ & $\mathrm{Si}$ & $\mathrm{P}$ & $\mathrm{S}$ & $\mathrm{Cr}$ & $\mathrm{Ni}$ \\
\hline 0,12 & 1,4 & \multicolumn{2}{|c|}{1,0} & 0,045 & 0,030 & \multicolumn{2}{c|}{$17,0 \div 19,0$} & $8,0 \div 10,0$ \\
\hline \multicolumn{7}{|c|}{ Własności mechaniczne } \\
\hline $\mathrm{R}_{\mathrm{e}} \mathrm{MPa}$
\end{tabular}

Tablica III. Skład chemiczny oraz własności wytrzymałościowe spoiwa CuSi3Mn1 - CastoMag 45706 (zgodne z PN-EN 13347:2004) Table III. Chemical composition and mechanical properties of CuSi3Mn1 filler material - CastoMag 45706 (according to PN-EN 13347:2004 standards)

\begin{tabular}{|c|c|c|c|c|}
\hline \multicolumn{5}{|c|}{ Zawartość składników stopowych [\%] } \\
\hline $\mathrm{Cu}$ & \multicolumn{2}{|c|}{$\mathrm{Si}$} & $\mathrm{Mn}$ & inne \\
\hline 95,7 & \multicolumn{2}{|c|}{2,9} & 0,9 & maks. 0,5 \\
\hline \multicolumn{5}{|c|}{ Własności wytrzymałościowe w temperaturze $20^{\circ} \mathrm{C}$} \\
\hline $\begin{array}{c}\text { Umowna granica } \\
\left.\text { plastyczności } \mathrm{Rp}_{0,2^{2}}, \mathrm{MPa}\right]\end{array}$ & $\begin{array}{c}\text { Granica wytrzymałości } \\
\mathrm{R}_{\mathrm{m}}, \mathrm{MPa}\end{array}$ & Wydłużenie $A_{5}, \%$ & Udarność, J & Twardość, HB \\
\hline 150 & 350 & 40 & 50 & 80 \\
\hline
\end{tabular}


Tablica IV. Skład chemiczny oraz własności wytrzymałościowe spoiwa CuSiMnAl - Mecufil 903 Al (zgodne z normą DIN 1733)

Table IV. Chemical composition and mechanical properties of CuSiMnAl filler material - Mecufil $903 \mathrm{Al}$ (according to DIN 1733 standards)

\begin{tabular}{|c|c|c|c|c|}
\hline \multicolumn{5}{|c|}{ Zawartość składników stopowych [\%] } \\
\hline \multicolumn{2}{|l|}{$\mathrm{Cu}$} & Si & $\mathrm{Mn}$ & Al \\
\hline \multicolumn{2}{|l|}{ baza } & 2,5 & 1,0 & 1,5 \\
\hline \multicolumn{5}{|c|}{ Własności wytrzymałościowe w temperaturze $20^{\circ} \mathrm{C}$} \\
\hline $\begin{array}{c}\text { Umowna granica } \\
\text { plastyczności } \mathrm{Rp}_{0,2^{\prime}} \mathrm{MPa}\end{array}$ & $\begin{array}{c}\text { Granica wytrzymałości } \\
\mathrm{R}_{\mathrm{m}}, \mathrm{MPa} \\
\end{array}$ & Wydłużenie $A_{5}, \%$ & Udarność, J & Twardość, HB \\
\hline$>360$ & 500 & $>40$ & - & - \\
\hline
\end{tabular}

Tablica V. Warunki technologiczne procesu lutospawania łukowego metodą CBT

Table V. Technological conditions of CBT arc braze welding process

\begin{tabular}{|c|c|}
\hline \multicolumn{2}{|c|}{ Parametry procesu lutospawania łukowego metodą CBT } \\
\hline Rodzaj gazu osłonowego & $100 \% \mathrm{Ar}$ \\
\hline Rodzaj drutu proszkowego & MECUFIL 903 Al, średnica: $1,2 \mathrm{~mm}$ \\
\hline Rodzaj drutu litego & CastoMag 45706, średnica: $1,0 \mathrm{~mm}$ \\
\hline Rodzaj prądu & $\mathrm{DC}$ Puls \\
\hline Prędkość przepływu gazu ochronnego & $15 \mathrm{dm}^{3} / \mathrm{min}^{\circ}$ \\
\hline Kąt pochylenia palnika & $75^{\circ}$ \\
\hline Wolny wylot elektrody & $15 \mathrm{~mm}$ \\
\hline
\end{tabular}

Łuk elektryczny przy lutospawaniu skierowany był na miedź z przesunięciem ok. $1 \div 2 \mathrm{~mm}$ od krawędzi blachy (rys. 1). Takie ustawienie uchwytu spawalniczego pozwoliło na wprowadzenie większej ilości ciepła do blachy miedzianej i lepsze zwilżenie powierzchni przez lut. Pochylenie uchwytu spawalniczego w stosunku do materiału podstawowego pod kątem $75^{\circ}$ ograniczało ilość rozprysków, zapewniało stabilniejsze przechodzenie kropli metalu do jeziorka oraz pozwalało na uzyskanie płaskiego i gładkiego lica.

Szczegółowe parametry przy których wykonano płyty próbne przedstawiono w tablicy VI, natomiast w tablicy VII ocenę wizualną złączy wraz ze średnimi wymiarami kształtu lica i grani.
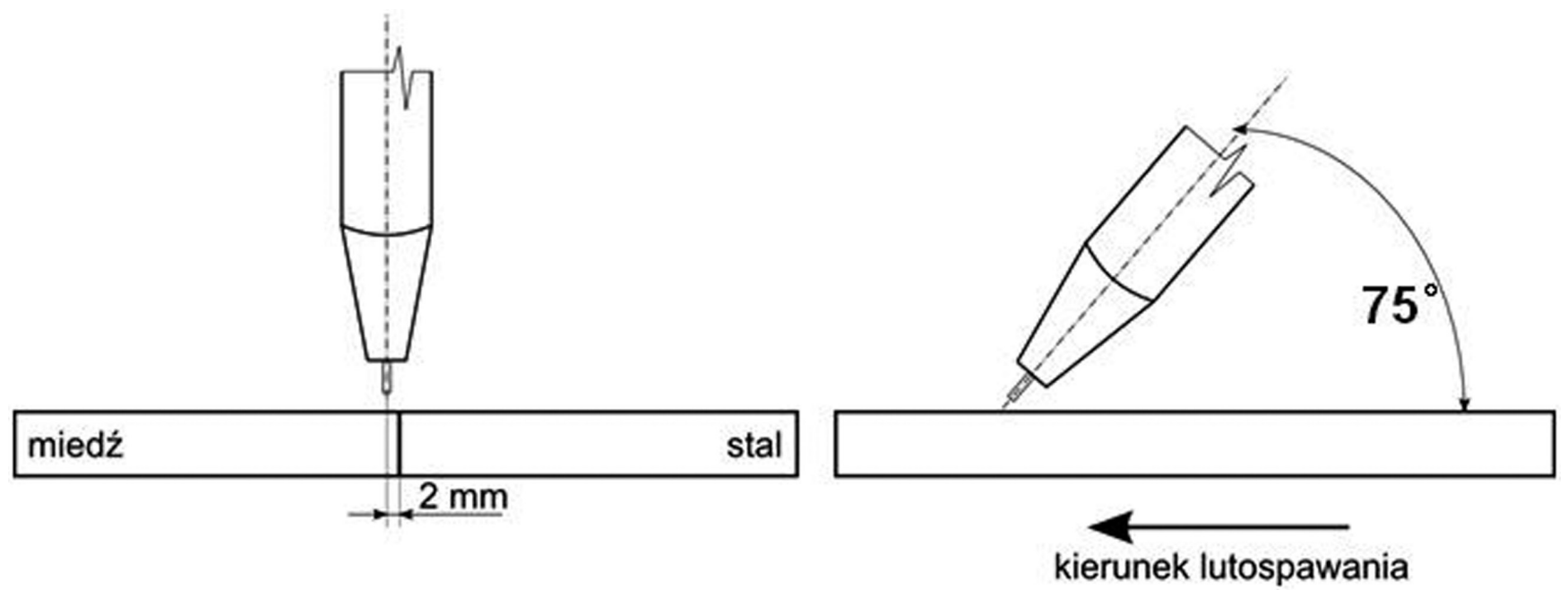

Rys. 1. Pochylenie uchwytu spawalniczego w stosunku do materiału lutospawanego w czasie procesu lutospawania łukowego metodą CBT Fig. 1. Angle between welding gun and braze welded material during CBT arc braze welding process

Tablica VI. Parametry procesu lutospawania łukowego CBT złączy różnoimiennych Table VI. Parameters of dissimilar joints CBT arc braze welding process

\begin{tabular}{|c|c|c|c|c|c|}
\hline $\begin{array}{c}\text { Rodzaj połączenia } \\
\text { Oznaczenie próbki }\end{array}$ & $\begin{array}{c}\text { Rodzaj } \\
\text { spoiwa }\end{array}$ & $\begin{array}{c}\text { Natężenie prądu } \\
\text { I, [A] }\end{array}$ & $\begin{array}{c}\text { Napięcie łuku } \\
\text { U, [V] }\end{array}$ & $\begin{array}{c}\text { Prędkość } \\
\text { spawania v [cm/s] }\end{array}$ & $\begin{array}{c}\text { Energia liniowa } \\
\mathrm{E}[\mathrm{kJ} / \mathrm{cm}]\end{array}$ \\
\hline Cu-1H18N9 C1 & CastoMag 45706 & 120 & 20,8 & 0,4 & 6,24 \\
\hline Cu-1H18N9 M1 & Mecufil 903 Al & 130 & 21,2 & 0,4 & 6,89 \\
\hline
\end{tabular}


Tablica VII. Wymiary geometryczne i ocena wizualna złączy różnoimiennych wykonanych w procesie lutospawania łukowego metodą CBT Table VII. Geometrical dimensions and visual assessment of CBT arc braze welded dissimilar joints

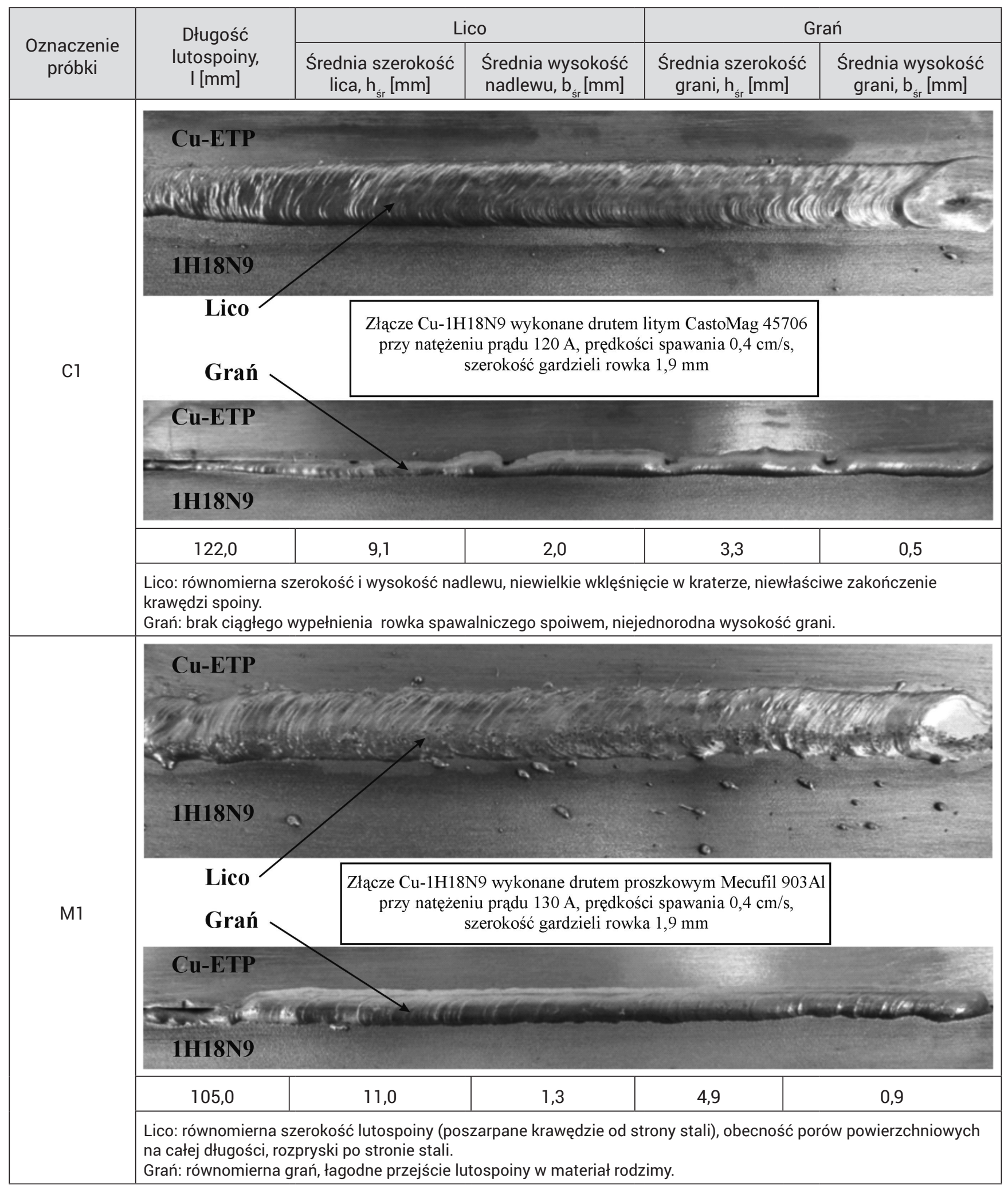

Podczas procesu lutospawania nie zaobserwowano odkształceń spawalniczych łączonych blach. W każdym przypadku, na początkowym odcinku złącza, występowało niepełne wypełnienie rowka spawalniczego z uwagi na zbyt szybkie odprowadzanie ciepła przez miedź, a słaba zwilżalność przez spoiwo powodowała jego zbyt wolne wnikanie w głąb szczeliny. Jednak w dalszej części złącza lutospoina wypełniała rowek spawalniczy, grań była równomierna i łagodnie przechodziła do materiału podstawowego. Złącze oznaczone jako próbka C1 charakteryzowało się najbardziej regularnym kształtem lica i grani lutospoiny, bez rozprysków i porowatości powierzchniowej, jednak odznaczało się nierównomierną szerokością i wysokością grani. W próbce M1 pobranej ze złącza wykonanego drutem proszkowym Mecufil 903 Al, występował znaczny rozprysk, szczególnie po stronie stali nierdzewnej. Niesymetryczny rozprysk był związany ze znaczną różnicą w przewodności cieplnej materiałów: miedzi i stali. Stal nierdzewna wolniej odprowadzała ciepło, dlatego krople ciekłego metalu przyklejały się do powierzchni blach, co nie miało miejsca po stronie blachy miedzianej. Ponadto, w złączach wykonanych drutem proszkowym od strony lica widoczne były pory na całej długości lutospoiny. Mimo zaobserwowanych niezgodności, w złączach nie występowały niezgodności typu pęknięcia, 
podtopienia lub głębokie i ciągłe niewypełnienie rowka spawalniczego, które zaliczane są do wad niedopuszczalnych, dyskwalifikujących złącza w ich eksploatacji.

Badania niszczące i mikroskopowe pozwoliły na ocenę właściwości wykonanych połączeń. Zastosowano próbę statycznego rozciągania złączy przeprowadzoną zgodnie z PN-EN ISO 6892-1:2010, próbę zginania poprzecznego złączy z rozciąganiem od strony lica i grani lutospoiny zgodnie z zaleceniami zawartymi w PN-EN ISO 5173 oraz badania makro i mikroskopowe. Próby statycznego rozciągania złączy doczołowych, w których poprzez obróbkę mechaniczną usunięto nadlew i lico lutospoin, przeprowadzono na maszynie wytrzymałościowej z wykorzystaniem głowicy pomiaru o maksymalnej sile badawczej wynoszącej $100 \mathrm{kN}$. Wyniki prób rozciągania złączy doczołowych zamieszczono w tablicy VIII.

Tablica VIII. Wynik prób statycznego rozciągania próbek pobranych ze złączy doczołowych, różnoimiennych wykonanych w procesie lutospawania łukowego metodą CBT

Table VIII. Results of tensile strength tests of CBT arc braze welded dissimilar butt welds

\begin{tabular}{|c|c|c|c|c|}
\hline $\begin{array}{l}\text { Oznaczenie } \\
\text { próbki }\end{array}$ & $\begin{array}{l}\text { Powierzchnia przekroju po- } \\
\text { czątkowego próbki, So [mm²] }\end{array}$ & $\begin{array}{l}\text { Wartość siły max } \\
\text { obciążenia, F [kN] }\end{array}$ & $\begin{array}{c}\text { Wytrzymałość } \\
\text { na rozciąganie, } \mathrm{Rm}\left[\mathrm{N} / \mathrm{mm}^{2}\right]\end{array}$ & Miejsce zerwania próbki \\
\hline C1-A & 69,4 & 15,6 & 224,8 & miedź - zerwanie w SWC \\
\hline C1-B & 78,9 & 15,2 & 192,7 & $\begin{array}{l}\text { miedź - zerwanie wzdłuż } \\
\text { lutospoiny }\end{array}$ \\
\hline \multicolumn{5}{|c|}{ Próbka C1-A } \\
\hline \multicolumn{5}{|c|}{ Cu-ETP } \\
\hline \multicolumn{5}{|c|}{ Próbka C1-B } \\
\hline \multicolumn{5}{|c|}{ Cu-ETP } \\
\hline M1-A & 68,1 & 15,7 & 230,5 & miedź - zerwanie w SWC \\
\hline M1-B & 68,5 & 15,4 & 224,8 & miedź - zerwanie w SWC \\
\hline
\end{tabular}

\section{Próbka M1-A}

Cu-ETP

\section{Próbka M1-B}


Statyczna próba rozciągania lutospawanych łukowo złączy doczołowych różnoimiennych wykazała niższą wytrzymałość mechaniczną połączeń niż wytrzymałość spoiwa (tabl. III i IV). Jednak w przypadku wytrzymałości na rozciąganie otrzymane wyniki bliskie były wytrzymałości miedzi. W trzech na cztery wykonanych prób wytrzymałościowych zerwanie nastąpiło po stronie miedzi, w obszarze SWC, a raz w miedzi blisko lutospoiny, gdzie mogło dojść do zmiękczenia miedzi i pogorszenia jej własności wytrzymałościowych. Złącza wykonane drutem litym CastoMag 45706 charakteryzowały się zbliżonymi własnościami do połączeń wykonanych drutem proszkowym Mecufil $903 \mathrm{Al}$.

Próby zginania poprzecznego z rozciąganiem od strony lica i grani złączy doczołowych różnoimiennych umożliwiły sprawdzenie plastyczności złączy oraz wykrycie możliwych niezgodności powstałych podczas procesu lutospawania. Próby zginania przeprowadzono z wykorzystaniem głowicy pomiaru siły $20 \mathrm{kN}$, używając stołu do zginania z dwoma podporami w postaci równoległych trzpieni o średnicy $20 \mathrm{~mm}$ i oddalonych od siebie o $85 \mathrm{~mm}$. Odkształcenia plastycznego próbek dokonała głowica gnącą uzbrojona w element gnący (trzpień gnący o średnicy $D=30 \mathrm{~mm}$ ). Podczas pracy maszyny próbki, w których wcześniej poprzez obróbkę mechaniczną usunięto nadlew i lico lutospoin, ulegały odkształceniu plastycznemu przez jednokierunkowe zginanie na całej szerokości lutospoiny w sposób powodujący rozciąganie jednej z powierzchni do momentu osiągnięcia pełnego kąta zgięcia $\left(150^{\circ}\right)$ lub pęknięcia próbki. Gięcie każdorazowo występowało po stronie miedzi, zaraz za lutospoiną. Miejsce gięcia było spowodowane dużą plastycznością miedzi, zdecydowanie większą niż plastyczność stali austenitycznej. Nie zaobserwowano pęknięć lub naderwań. Widok próbek po próbie zginania przedstawiono na rysunkach 2 i 3.
Badania metalograficzne przeprowadzono w celu oceny poprawności wykonania złączy w skali makro i mikroskopowej. Stal nierdzewna austenityczna 1H18N9 wytrawiono odczynnikiem Adlera. Miedź i lutospoina zostały wytrawione w odczynniku: $\mathrm{K}_{2} \mathrm{Cu}_{2} \mathrm{O}_{7}+100 \mathrm{~cm}^{3} \mathrm{H}_{2} \mathrm{O}+4 \mathrm{~cm}^{3} \mathrm{NaCl}+8 \mathrm{~cm}^{3}$ $\mathrm{H}_{2} \mathrm{SO}_{4}$. Zdjęcia makrostruktury złączy wraz z obrazami mikrostruktury przedstawiają obszary materiału rodzimego, SWC, linii przejścia lutospoiny i materiału łączonego, a także obszary, w których pojawiły się pęknięcia i znaczny rozrost ziarna w strukturze (rys. 4 i 5 ).

Na podstawie makrostruktury wykonanych złączy stwierdzono niesymetryczną krystalizację lutospoiny spowodowaną różnicą w przewodności cieplnej miedzi i nierdzewnej stali austenitycznej. Po stronie miedzi w każdej lutospoinie widoczne są długie kolumnowe kryształy ułożone równolegle do kierunku odpływu ciepła. Po stronie miedzi występuje krystalizacja epitaksjalna - zarodkami krystalizacji są częściowo roztopione kryształy miedzi w materiale podstawowym. Narastające kryształy w lutospoinie cechują się zachowaną orientacją krystalograficzną. Obrazy makroskopowe wskazują na znaczny rozrost ziaren w blachach miedzianych.

W wyniku badań mikrostrukturalnych złączy różnoimiennych zbadano wpływ wprowadzonego ciepła na strukturę materiałów podstawowych. W przypadku stali nierdzewnej austenitycznej 1H18N9 w obydwu złączach (próbki C1 i M1) nie zaobserwowano znacznego rozrostu ziarna, jednak w blachach na styku powierzchnia górna blachy - lutospoina wystąpiły pęknięcia po granicach ziaren w głąb materiału (rys. 4c i 5f). Mniejszą ilość pęknięć zaobserwowano w próbce $\mathrm{M} 1$, złącze $\mathrm{Cu}-1 \mathrm{H} 18 \mathrm{~N} 9$, wykonane drutem proszkowym Mecufil 903 Al. W żadnej lutospoinie nie stwierdzono pęknięć, pęcherzy gazowych lub innych wad wewnętrznych.
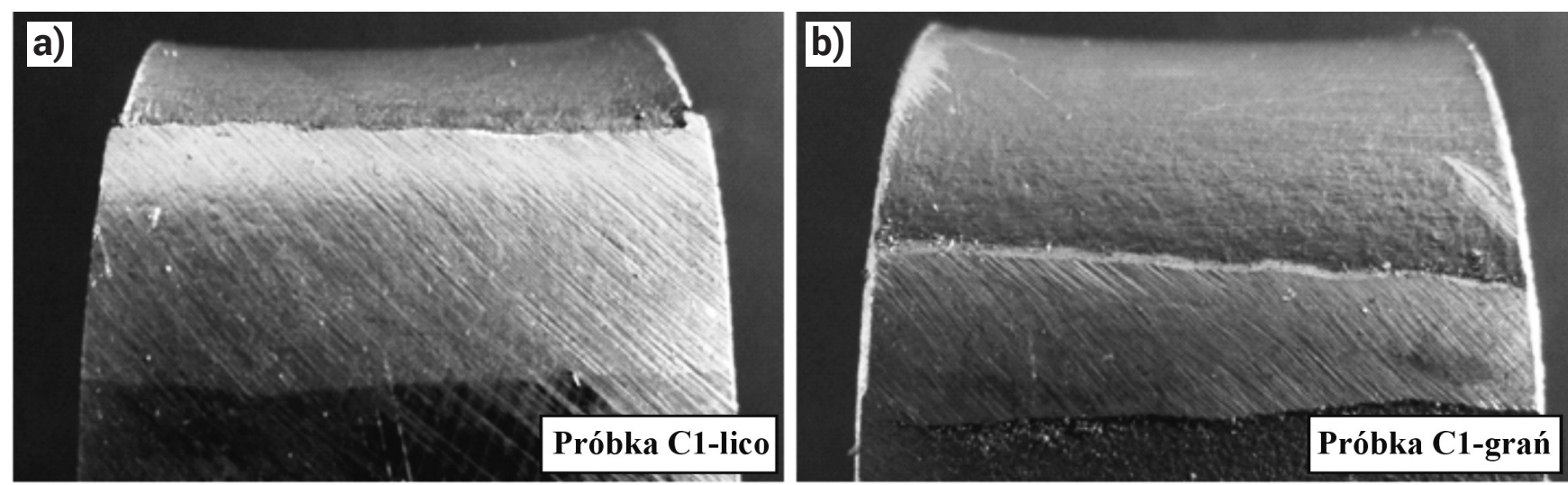

Rys. 2. Próbka $\mathrm{C} 1$ pobra z lutospawanego łukowo metodą $\mathrm{CBT}$ złącza doczołowego $\mathrm{Cu}-1 \mathrm{H} 18 \mathrm{~N} 9$ po próbie zginania z rozciąganiem poprzecznym: a) lico i b) grań

Fig. 2. A view of $\mathrm{C} 1$ specimen from $\mathrm{CBT}$ arc braze welded $\mathrm{Cu}-1 \mathrm{H} 18 \mathrm{~N} 9$ butt joint after bending test with transverse tensile: a) weld face, b) weld root
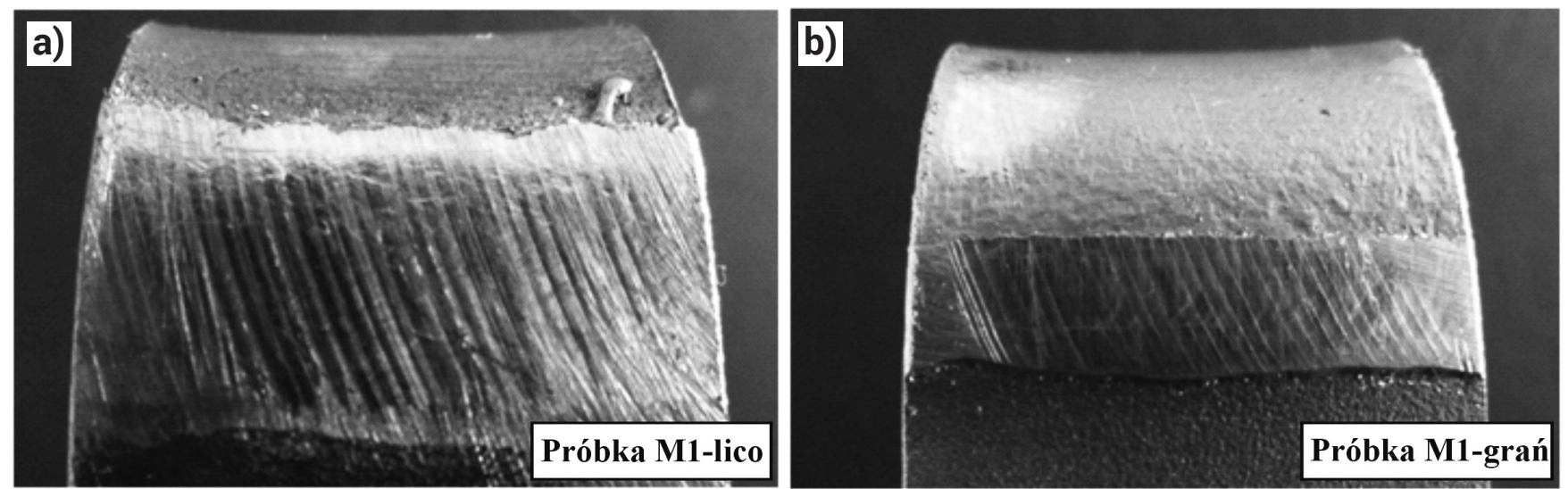

Rys. 3. Próbka M1 pobrana z lutospawanego łukowo metodą CBT złącza doczołowego Cu-1H18N9 po próbie zginania z rozciąganiem poprzecznym: a) lico i b) grań

Fig. 3. A view of M1 specimen from CBT arc braze welded $\mathrm{Cu}-1 \mathrm{H} 18 \mathrm{~N} 9$ butt joint after bending test with transverse tensile: a) weld face, b) weld root 

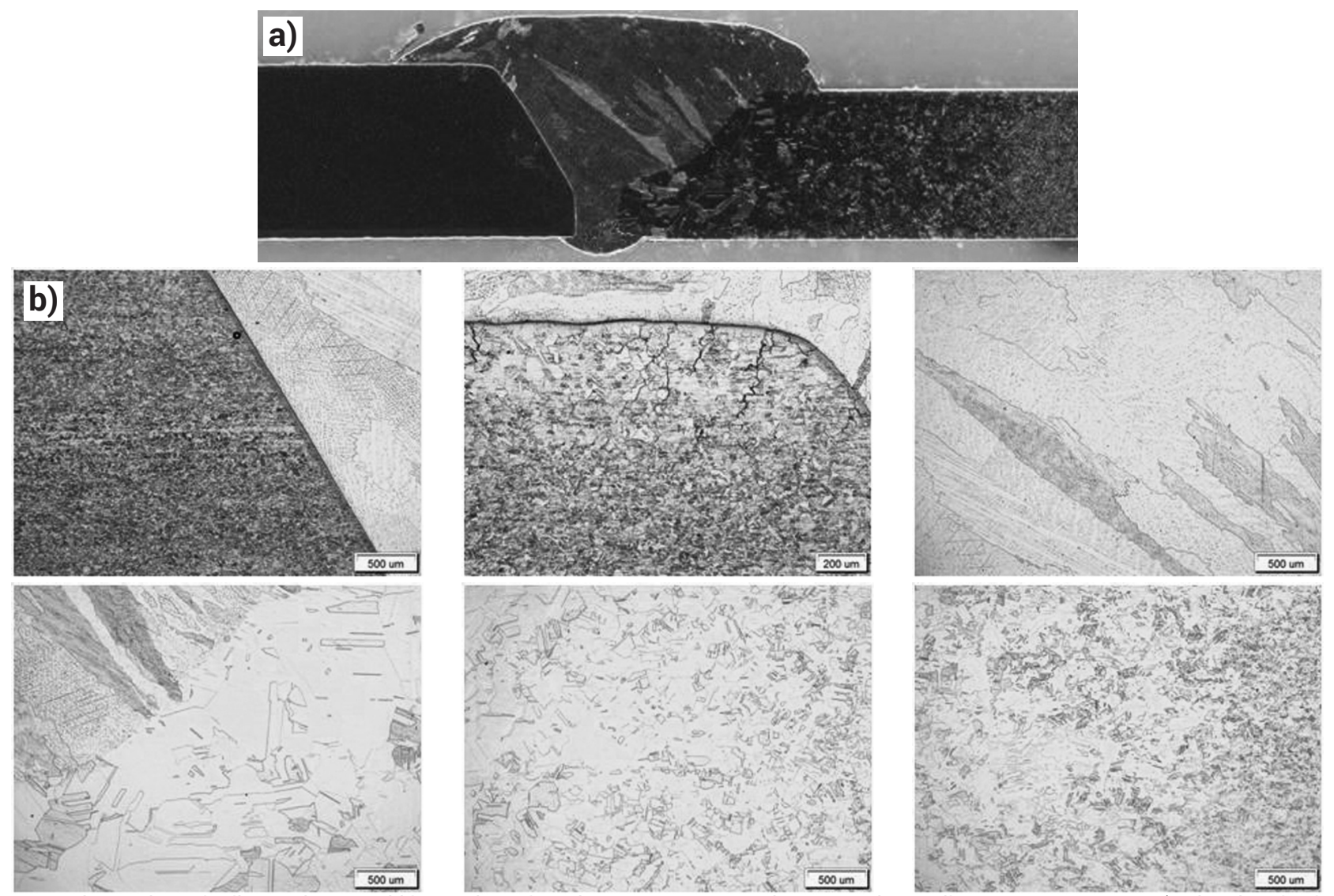

Rys. 4. Makrostruktura i mikrostruktura próbki C1 pobranej ze złącza Cu-1H18N9 wykonanego drutem litym CastoMag 45706 (stal po lewej, miedź po prawej stronie): a) makrostruktura złącza; b) mikrostruktura obszaru na styku stal nierdzewna austenityczna - lutospoina; c) mikrostruktura obszaru na styku: stal nierdzewna - lutospoina; d) mikrostruktura lutospoiny; e) mikrostruktura obszaru na styku: lutospoina - miedź; f) mikrostruktura obszaru SWC miedzi; g) mikrostruktura przejścia z SWC do materiału rodzimego miedzi

Fig. 4. A view of macro and microstructure of $\mathrm{C} 1$ specimen from $\mathrm{Cu}-1 \mathrm{H} 18 \mathrm{~N} 9$ joint brazed with CastoMag 45706 solid wire (steel is on the left, cooper is on the right): a) welded joint macrostructure; b) microstructure of austenitic stainless steel and braze weld contact area; c) microstructure of austenitic steel and braze weld contact area; d) microstructure of braze weld; e) microstructure of contact area between braze weld and cooper; f) microstructure of cooper $\mathrm{HAZ} ; \mathrm{g}$ ) microstructure of transition zone from $\mathrm{HAZ}$ to base material
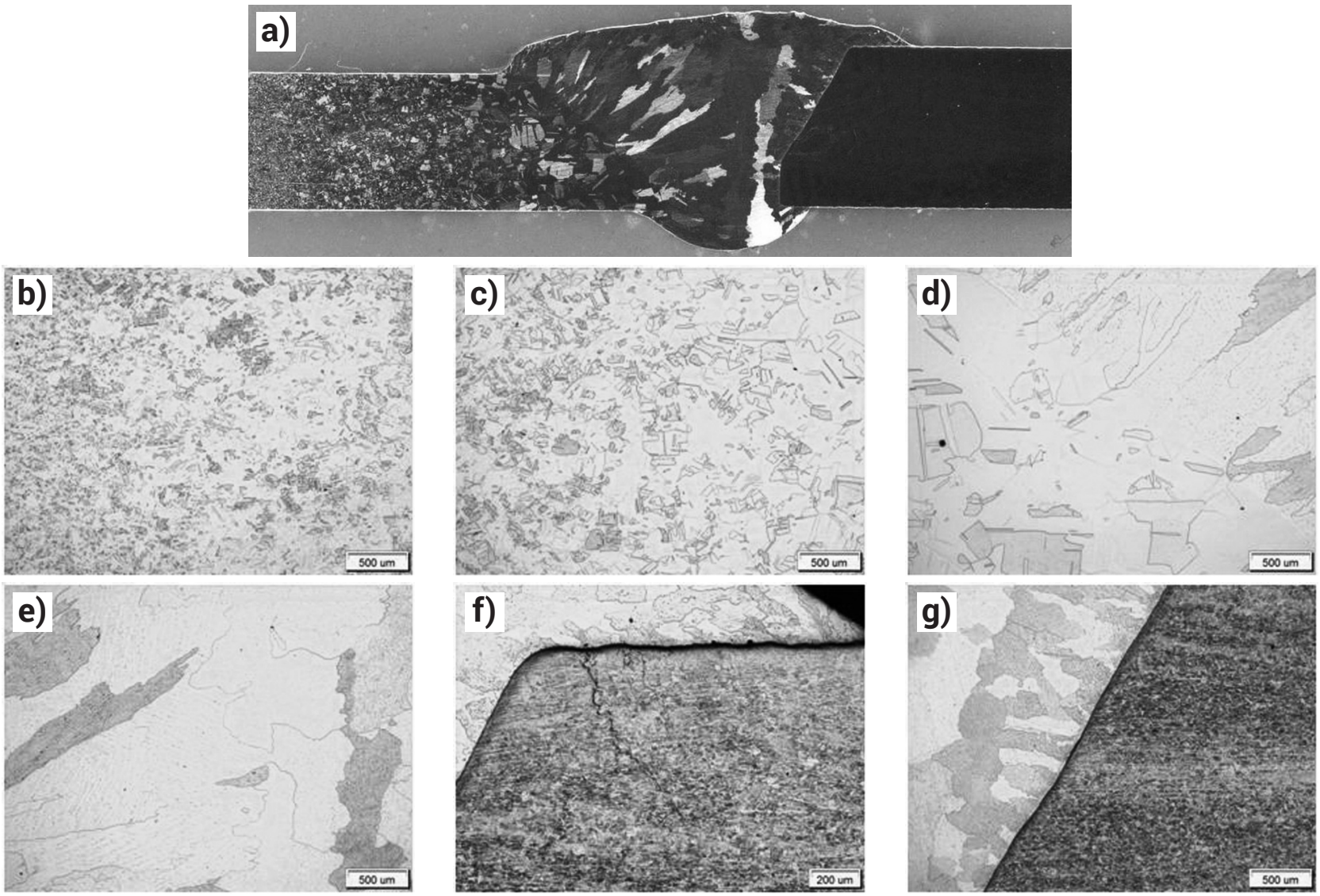

Rys. 5. Makrostruktura i mikrostruktura próbki M1 pobranej ze złącza Cu-1H18N9 wykonanego drutem proszkowym Mecufil 903 Al (miedź po lewej, stal po prawej stronie): a) makrostruktura złącza; b) mikrostruktura obszaru materiału rodzimego miedzi; c) mikrostruktura przejścia z materiału rodzimego do SWC miedzi; d) mikrostruktura obszaru na styku: miedź - lutospoina; e) mikrostruktura lutospoiny; f) mikrostruktura obszaru na styku: stal nierdzewna austenityczna - lutospoina; g) mikrostruktura obszaru na styku: lutospoina - stal nierdzewna austenityczna

Fig. 5. A view of macro and microstructure of M1 specimen from Cu-1H18N9 joint brazed with Mecufil $903 \mathrm{Al}$ solid wire (cooper is on the left, steel is on the right): a) welded joint macrostructure; b) microstructure of cooper base material; c) microstructure of transition zone between base material and cooper HAZ; d) microstructure of contact area: cooper - braze weld; e) microstructure of braze weld; f) microstructure of contact area: austenitic stainless steel - braze weld; g) microstructure of contact zone: weld braze -austenitic stainless steel 
Dokładniejsze badania przeprowadzone na skaningowym mikroskopie elektronowym umożliwiły sprawdzenie charakteru pęknięć w blachach nierdzewnych austenitycznych 1H18N9 złączy różnoimiennych, zmierzenie grubości i ocenę równomierności strefy dyfuzyjnej w badanych złączach. Na obrazie SEM próbki C1 - złącze Cu-1H18N9 wykonane drutem litym CastoMag 45706 - widoczne są pęknięcia o charakterze międzykrystalicznym, usytuowane w SWC, propagujące od powierzchni blachy nierdzewnej do wewnątrz materiału (rys. 6b i 6c).

Zdjęcia przedstawione na rysunkach. $6 \mathrm{~b}$ oraz $6 \mathrm{c}$ wskazują na wnikanie lutospoiny miedzianej w głąb stali austenitycznej. Podczas obserwacji przy większych powiększeniach: x2000 i x5000 stwierdzono obecność nieciągłości w lutospoinie, równoległych do powierzchni blachy stalowej austenitycznej, określonych jako wtrącenia niemetaliczne (rys. $6 \mathrm{f}$ i $6 \mathrm{~g}$ ). Podobne pęknięcia w stali austenitycznej zaobserwowano na obrazach SEM próbki M1 pobranej ze złącza Cu-1H18N9 wykonanego drutem proszkowym Mecufil 903Al (rys. 7b $\div 7 \mathrm{e}$ ). Lokalizacja pęknięć $w$ próbce $M 1$, miejsce ich rozpoczęcia, a także dalsze rozprzestrzenianie po granicach ziaren są zbieżne z pęknieciami występującymi w próbce $\mathrm{C} 1$. W lutospoinie próbki M1 zaobserwowano także nieciągłości równoległe do powierzchni blachy nierdzewnej, jednak zdecydowanie mniejsze niż w próbce $\mathrm{C} 1$.

Rysunki $6 f$ i $6 \mathrm{~g}$ oraz $7 \mathrm{f}$ i $7 \mathrm{~g}$ przedstawiają warstwę dyfuzyjną w stali nierdzewnej austenitycznej, złączy Cu-1H18N9 wykonanych odpowiednio drutem litym CastoMag 45706 (próbka C1) oraz drutem proszkowym Mecufil 903Al (próbka M1), powstałą na skutek zjawiska wzajemnej dyfuzji materiału podstawowego i stopiwa. Grubość warstwy dyfuzyjnej w obu przypadkach była równomierna w całym obszarze styku lutospoiny z nierdzewną stalą austenityczną i wynosiła średnio 4,8918 4 m dla próbki C1 oraz 1,6233 um dla próbki M1. Nie zaobserwowano warstwy dyfuzyjnej po stronie miedzi.

$\mathrm{Na}$ podstawie przedstawionych obrazów wykonanych przy dużym powiększeniu wyraźnie widać, że pęknięcia
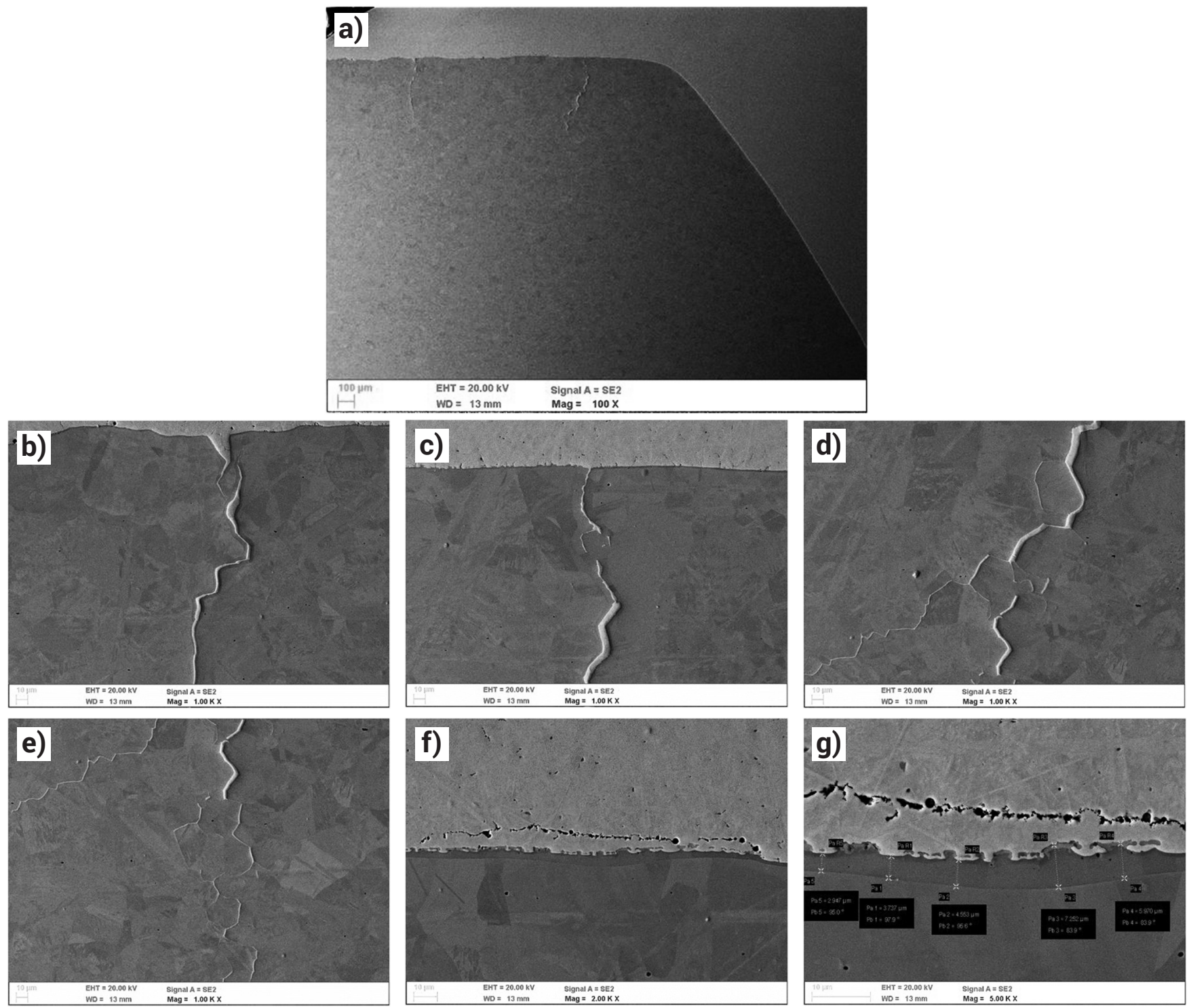

Rys. 6. Obraz SEM próbki C1 pobranej ze złącza Cu-1H18N9. Widok stali nierdzewnej austenitycznej wraz z lutospoiną wykonaną drutem litym CastoMag 45706: a) obraz ogólny (pow. x100); b) obraz SEM pęknięcia międzykrystalicznego w stali (pow. x1000); c) obraz SEM pęknięcia międzykrystalicznego w stali (pow. x1000); d) propagacja pęknięcia po granicach ziaren austenitu (pow. x1000); e) ciąg dalszy rozprzestrzeniania się pęknięcia po granicach ziaren austenitu (pow. x1000); f) wtrącenia niemetaliczne w lutospoinie po stronie stali, równoległe do powierzchni blachy stalowej (pow. x2000); g) wtrącenia niemetaliczne w lutospoinie, równoległe do powierzchni blachy stalowej oraz widok warstwy dyfuzyjnej w stali (pow. x5000)

Fig. 6. SEM picture of $\mathrm{C} 1$ specimen from $\mathrm{Cu}-1 \mathrm{H} 18 \mathrm{~N} 9$ braze welded joint. A view of austenitic stainless steel with braze weld - filler material: CastoMag 45706: a) general picture; b) SEM picture of intercrystalline crack in steel area (magnification x1000); c) SEM picture of intercrystalline crack in steel area (magnification x1000); d) cracks propagation on the austenite grains boundaries (magnification $\times 1000$ ); e) continuation of cracks propagation on the austenite grains boundaries (magnification $x 1000$ ); $f$ ) non-metallic inclusions in braze weld on the steel side, parallel to steel plate surface (magnification $\mathrm{x} 2000$ ); $\mathrm{g}$ ) non-metallic inclusions in braze weld, parallel to steel plate surface and view of diffusion layer in steel (magnification x5000) 
w złączach różnoimiennych Cu-1H18N9 wykonanych drutem litym CastoMag 45706 (próbka C1) oraz drutem proszkowym Mecufil 903 Al (próbka M1) mają taki sam charakter. Powstałe pęknięcia zlokalizowane są obszarze SWC, a ich propagacja powstała po granicach ziaren.

Mechanizm powstawania pęknięć w SWC stali austenitycznej jest wynikiem wspólnego działania ciekłej fazy miedzi na granicach ziaren i odkształceń związanych $z$ procesem skurczu w stali. Podczas lutospawania łuk elektryczny skierowany był na blachę miedzianą, jednak ilość wprowadzonego ciepła do stali była stosunkowo duża. W procesie krystalizacji lutospoiny, w stali wystąpiły naprężenia rozciągające (prostopadłe do granic ziaren) intensyfikowane szybszym odprowadzaniem ciepła przez miedź. Powstałe naprężenia ułatwiły zwilżanie granic ziaren cienką warstewką cieczy (miedzi i pozostałych składników lutospoiny). Płynne warstewki cieczy osłabiły granice ziaren, ponieważ nie przenoszą odkształceń plastycznych powstałych na skutek chłodzenia. W wyniku chłodzenia, w SWC powstały nieciągłości o charakterze międzykrystalicznym, które rozprzestrzeniły się w głąb stali (rys. 6 i 7).

Nieciągłości obecne $\mathrm{w}$ lutospoinie po stronie stali austenitycznej, usytuowane równolegle do powierzchni blachy, widoczne przy powiększeniach x1000, x2000 i x5000, widoczne na rysunkach $6 \mathrm{f}$ i $7 \mathrm{f}$, mają charakter małych wtrąceń niemetalicznych - tlenkowych. Prawdopodobnie przed lutospawaniem na powierzchni stali austenitycznej utworzyła się wysokotopliwa warstwa tlenków chromu $\mathrm{Cr}_{2} \mathrm{O}_{3} \circ \mathrm{T}_{\mathrm{t}}=2437^{\circ} \mathrm{C}$. Niedokładne usunięcie warstwy tlenkowej, przyczyniło się do pozostania warstwy pasywnej na powierzchni blachy nierdzewnej. Z uwagi na niskoenergetyczny proces łączenia blach nie doszło do redukcji tlenków, dlatego pozostały w lutospoinie, blisko powierzchni stali austenitycznej. Należy zauważyć, iż po stronie stali zachodzi proces lutowania, przez co wymagana jest dobra zwilżalność i rozpływność lutu na powierzchni blachy, dlatego tak istotne jest odpowiednie i staranne przygotowanie blach.
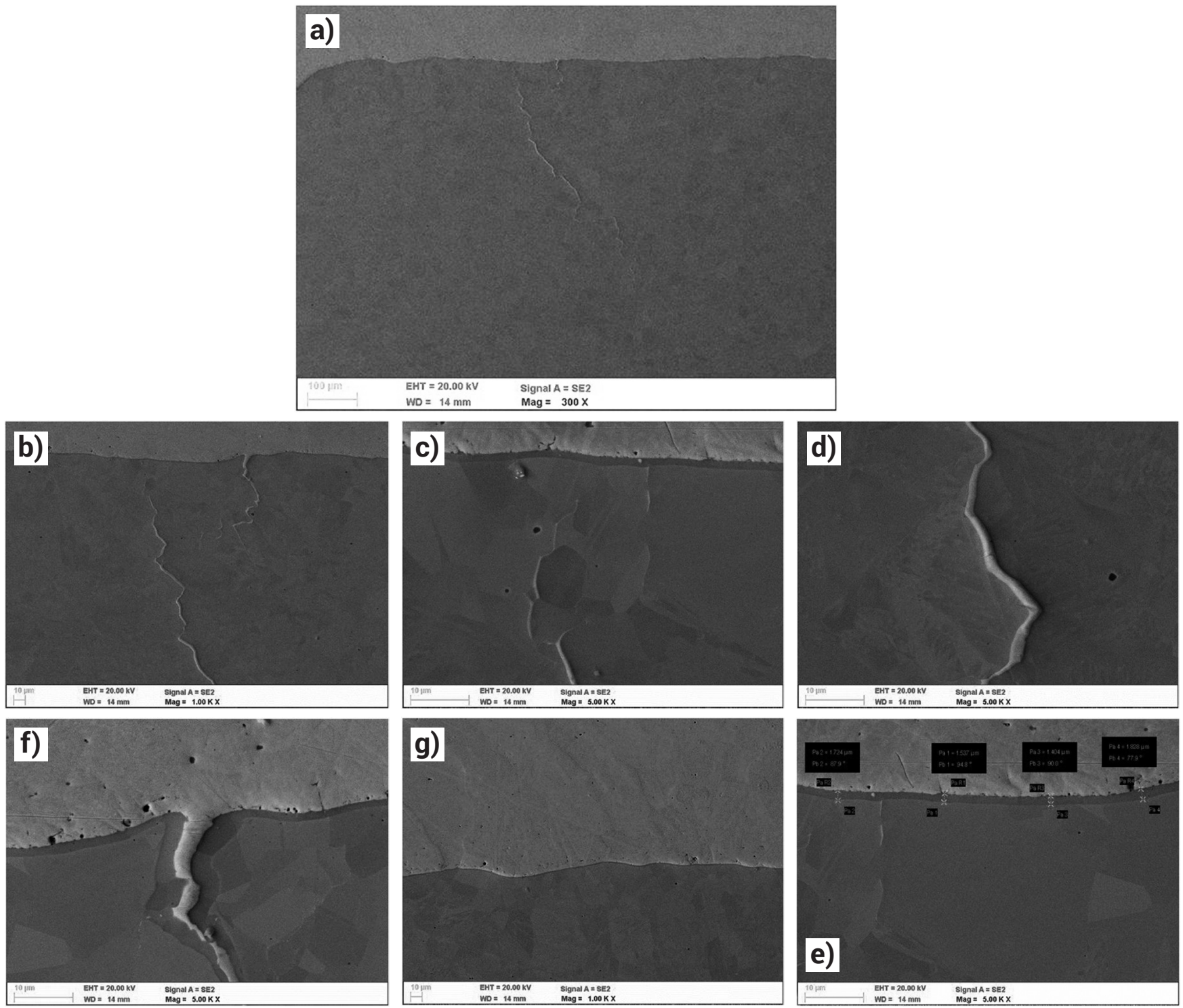

Rys. 7. Obraz SEM próbki M1 pobranej ze złącza Cu-1H18N9. Widok stali nierdzewnej austenitycznej wraz z lutospoiną wykonaną drutem proszkowym Mecufil 903 Al: a) obraz ogólny (pow. x300); b) obraz SEM pęknięć międzykrystalicznych w stali (pow. x1000); c) obraz SEM miejsca rozpoczęcia pęknięcia po granicach ziaren austenitu (pow. x5000); d) propagacja pęknięcia po granicach ziaren austenitu (pow. x5000); e) obraz SEM miejsca rozpoczęcia pęknięcia po granicy ziaren z obecną warstwą dyfuzyjną (pow. x5000); f) wtrącenia niemetaliczne w lutospoinie, równoległe do powierzchni blachy stalowej (pow. x1000); g) wtrącenia niemetaliczne w lutospoinie, równoległe do powierzchni blachy stalowej oraz widok warstwy dyfuzyjnej w stali (pow. x5000)

Fig. 7. SEM picture of $M 1$ specimen from $\mathrm{Cu}-1 \mathrm{H} 18 \mathrm{~N} 9$ braze welded joint. A view of austenitic stainless steel with braze weld - filler material: cored wire Mecufil $903 \mathrm{Al}$ : a) general picture (magnification x300); b) SEM picture of intercrystalline crack in steel area (magnification $\mathrm{x} 1000$ ); c) SEM picture of intercrystalline crack initiation area on austenite grains boundaries (magnification $x 5000$ ); d) cracks propagation on the austenite grains boundaries (magnification x5000); e) SEM picture of cracks initiation area on the austenite grains boundaries with diffusion layer (magnification x5000); f) non-metallic inclusions in braze weld on the steel side, parallel to steel plate surface (magnification x1000); g) non-metallic inclusions in braze weld, parallel to steel plate surface and view of diffusion layer in steel (magnification x5000) 
Próbę twardości wykonanych złączy przeprowadzono sposobem Vickersa zgodnie z normą PN-EN ISO 6507-1 na zgładach metalograficznych, które wcześniej posłużyły do badań makro- i mikrostrukturalnych. Pomiar twardości na przekroju poprzecznym wykonano w jednej linii pomiarowej dokonując pomiarów w materiale rodzimym, strefie wpływu ciepła oraz lutospoinie, przy zadanym obciążeniu $H_{0,2}$. Pomimo, iż w procesie lutospawania zastosowano niskie wartości natężenia prądu, tabl. 6, można zaobserwować zmianę twardości w materiałach podstawowych, jakimi były miedź oraz stal nierdzewna austenityczna. Różnice wynikały z obecności strefy wpływu ciepła w tychże materiałach. W miedzi w SWC zaznaczył się nieznaczny spadek twardości i tym samym gorsze własności wytrzymałościowe. Uzyskana twardość stali nierdzewnej austenitycznej 1H18N9 w strefie niezmienionej wynosiła ok. $170 \mathrm{HV}_{0,2}$. W miarę zbliżania się do lutospoiny twardość początkowo nieznacznie spadała do wartości ok.
$160 \mathrm{HV}_{0,2}$ jednak na styku blachy i lutospoiny twardość ponownie uzyskiwała wartości na poziomie materiału rodzimego. Zaobserwowano znaczne różnice w twardości na styku obszarów lutospoiny i stali nierdzewnej, wynoszące ok. $90 \mathrm{HV}_{0,2}$. W każdym złączu lutospoina charakteryzowała się prawie niezmienną twardością, mimo asymetrycznej budowy krystalograficznej. Na rys. 8 zestawiono wyniki pomiarów twardości złączy typu Cu-H18N9 (próbka C1 i M1), wykonanych odpowiednio drutem litym CastoMag 45706 i proszkowym drutem Mecufil 903Al. Na podstawie wyników badania twardości porównano średnią twardość lutospoiny wykonanej drutem litym CastoMag 45706 (próbki C1 i M1) oraz twardość lutospoiny wykonanej z użyciem drutu proszkowego Mecufil 903Al. Średnia twardość stopiwa CastoMag 45706 wynosiła 83,1 HV0,2, natomiast stopiwa Mecufil 903Al wynosiła 88,6 HVo,2, co świadczy o zbliżonych własnościach wytrzymałościowych stosowanych materiałów dodatkowych.

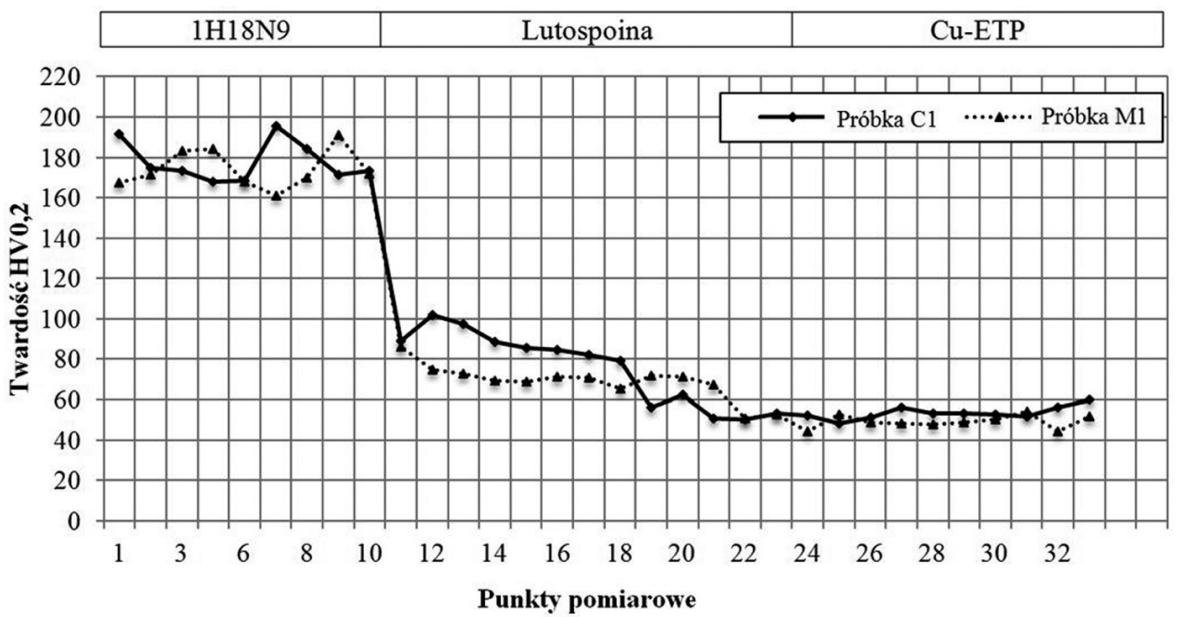

Rys. 8. Zestawienie twardości złączy różnoimiennych Cu-1H18N9, wykonanych drutem litym CastoMag 45706 (próbka C1) oraz drutem proszkowym Mecufil 903Al (próbka M1)

Fig. 8. Hardness overview of dissimilar joints Cu-1H18N9 with CastoMag 45706 filler material (C1 specimen) and Mecufil 903Al cored wire (M1 specimen)

\section{Wnioski}

W wyniku przeprowadzonych badań lutospawanych łukowo metodą CBT złączy różnoimiennych oraz analizy otrzymanych wyników sformułowano następujące wnioski:

1. Niskoenergetyczny proces lutospawania łukowego metodą CBT umożliwia uzyskanie dobrej jakości połączenia różnoimiennego typu miedź - stal 1H18N9 w zakresie optymalnych parametrów technologicznych.

2. Podczas lutospawania miedzi ze stalą austenityczną wystąpiły jednocześnie zjawisko zwilżenia i wzajemnej dyfuzji składników blachy stalowej i lutospoiny oraz nieznacznego stapiania bez zjawisk dyfuzyjnych po stronie blachy miedzianej.

3. W celu zapewnienia odpowiedniej jakości złączy różnoimiennych typu miedź - stal austenityczna istotne jest odpowiednie przygotowanie blach do procesu łączenia polegające na oczyszczeniu mechanicznym i odtłuszczeniu brzegów, dzięki czemu uniknie się warstw tlenkowych w lutospoine.

4. Złącza lutospawane z zastosowaniem drutu litego CastoMag 45706 z uwagi na znacznie mniejszą ilość rozprysków oraz brak porów powierzchniowych na licu lutospoiny spełniają wyższe kryteria jakościowe niż złącza wykonane drutem proszkowym Mecufil 903Al.

5. Miarą wytrzymałości statycznej złączy różnoimiennych miedź - stal austenityczna jest granica wytrzymałości miedzi w SWC, przez co pęknięcia międzykrystaliczne w stali 1H18N9 nie odgrywają istotnej roli w późniejszej eksploatacji złączy. 


\section{Literatura}

[1] Gawrysiuk W.: Technologia lutospawania łukowego. Zalecenia technologiczne i przemysłowe przykłady zastosowania, Biuletyn Instytutu Spawalnictwa 3 (2005), s. 35-40.

[2] Różański M.: Nowoczesne metody lutospawania, Przegląd Spawalnictwa 9 (2010), s. 24-28.

[3] Kudła K., Wojsyk K.: Czy sposób doprowadzania ciepła ma istotny wpływ na geometrię spoin?, Biuletyn Instytutu Spawalnictwa 5 (2012), s. 140-144.

[4] Gawrysiuk W., Pfeifer T., Winiowski A.: Charakterystyka Technologii lutospawania łukowego MIG/MAG, Przegląd Spawalnictwa 2-3 (2005), s. 17-20.

[5] Białucki P., Ambroziak A., Derlukiewicz W., Lange A., Bednarek T.: Wpływ lutospawania łukowego na właściwości złączy stali ocynkowanej ogniowo, Przegląd Spawalnictwa 9 (2013), s. 20-28.

[6] Matusiak J., Czworonóg B., Pfeifer T.: Nowe procesu spawania MIG/MAG o małej energii łuku w aspekcie ograniczania emisji zanieczyszczeń, Biuletyn Instytutu Spawalnictwa 5 (2007), s. 49-55.

[7] Matusiak J., Czworonóg B., Pfeifer T.: Spawanie i lutospawanie niskoenergetycznymi metodami MIG/MAG przeznaczonymi do łączenia materiałów i elementów wrażliwych na ciepło, Biuletyn Instytutu Spawalnictwa 6 (2007), s. 41-46.
[8] Bruckner J.: Metoda CMT - Rewolucja w technologii spawania, Przegląd Spawalnictwa 7-8 (2009), s. 24-28.

[9] Matusiak J., Czworonóg B.: Niskoenergetyczne procesy spawania łukowego w osłonie gazów do łączenia cienkich blach stalowych, Hutnik - Wiadomości Hutnicze 1 (2008), s. 10-16.

[10] De Dompablo M.: Nowe rozwiązania w technologii spawania ColdArc i forceArc, Przegląd Spawalnictwa 7-8 (2009), s. 12-17.

[11] Różański M., Gawrysiuk W.: Lutospawanie MIG/MAG blach ocynkowanych i przykłady trudno spawalnych układów materiałowych, Przegląd Spawalnictwa 9 (2007), s. 7-12.

[12] Mirski Z., Granat K., Winiowski A., Bulica A.: Porównanie metod spajania miedzi ze stalą austenityczną, Inżynieria Materiałowa 3 (2006), s. 205-208.

[13] Klimpel A., Czupryński A., Górka J., Kik T., Dratwa D.: Badania technologii automatycznego lutospawania PTA złączy absorbera kolektorów słonecznych, Przegląd Spawalnictwa 4 (2008), s. 11-16.

[14] Klimpel A., Górka J., Czupryński A., Kik T., Dadak R.: Badania technologii automatycznego lutowania miękkiego GTA elementów kolektora słonecznego, Przegląd Spawalnictwa 12 (2008), s. 3-8. 